\title{
ОСОБЛИВОСТІ МОРАЛЬНОЇ РЕГУЛЯЦІЇ СТОСУНКІВ МІЖ УЧАСНИКАМИ НАВЧАЛЬНО-ВИХОВНОГО ПРОЦЕСУ ДНЗ
}

\begin{abstract}
Федорович А. В. Особливості моральної регуляції стосунків між учасниками навчальновиховного процесу ДНЗ.

У статті розкрито роль етики у професійній діяльності дошкільного педагога; висвітлено основні моральні принципи педагогічної взаємодії (оптимізму, громадянськості, гуманізму, законності, справедливості, гендерної рівності, незалежності, взаємоповаги, довіри, доброзичливості, тактовності); підкреслено значення внутрішнього прийняття моральних вимог вихователем.

Ключові слова: дошкільний педагог, вихователь, етика взаємин, педагогічна етика, етичні принципи, моральні якості.
\end{abstract}

Федорович А. В. Особенности моральной регуляции отношений между участниками учебновоспитательного процесса ДУЗ.

В статье раскрыта роль этики в профессиональной деятельности дошкольного педагога; отражены основные моральные принципы педагогического взаимодействия (оптимизма, гражданственности, гуманизма, законности, справедливости, гендерного равенства, независимости, взаимного уважения, доверия, доброжелательности, тактичности и др.); подчеркнуто значение внутреннего принятия моральных требований воспитателем.

Ключевые слова: дошкольный педагог, воспитатель, этика взаимоотношений, педагогическая этика, нравственные принципы, моральные качества.

Fedorovych A. V. Features of moral regulation of relations between participants of educational process in pre-school.

In the article is exemined the role of ethics in professional activity of preschool teacher; basic moral principles of pedagogical co-operation(optimism; civility; humanism; legality; justice; gender equality; independence; mutual respect, trust, goodwill, tactfulness, and other) is underline; the value of internal acceptance of moral requirements of educator.

Key words: preschool teacher, educator, ethics of mutual relations, pedagogical ethics, ethic principles, moral quality

Нині зростають вимоги до дошкільного педагога, його професіоналізму, світоглядної культури, моральності, майстерності. Суспільство делегує йому свої повноваження та висуває моральний обов'язок гідно виконувати своє призначення. Він нарівні з батьками несе відповідальність за соціальну зрілість вихованця та розв'язує важливе завдання: забезпечити різнобічний розвиток кожної дитини відповідно до іiі задатків, нахилів, здібностей, індивідуальних, психічних та фізичних особливостей, культурних потреб.

Своєю діяльністю дошкільний педагог покликаний утверджувати ідеали добра, справедливості, честі, милосердя, любові. Йому необхідно підтримувати доброзичливі відносини 3 дітьми, а також встановлювати їх із законними представниками малюків батьками, родиною чи близькими людьми. Вихователь ДНЗ зрозуміло та об'єктивно має інформувати їх про стан навчання, виховання та розвитку дитини; консультувати щодо проблем виховання, передбачати конфліктні ситуації та допомагати розв'язувати їх у разі виникнення. Його професійна компетентність та авторитет грунтуються на здатності бути стриманим, чуйним, доброзичливим, принциповим, творчим. Найважливішими при цьому $\epsilon$ людська небайдужість, любов до дітей та розумна вимогливість. Саме на цих засадах міжособистісні взаємини учасників навчально-виховного процесу набувають статусу етичних, сприяючи інтеграції, єдності й толерантності у стосунках.

У педагогічній професії роль етики велика, оскільки сама мораль виконує педагогічні функції [12]. Власне ідеями моралі, гуманізму наповнена вся історія людських стосунків. 
Науковці завжди бачили людину вольовою, діяльною, яка перебуває в емоційному взаємозв'язку зі світом. Мораль сприймалася як вищий принцип гуманізму, критерій людського життя. Совість, добро, справедливість, співчуття, доброчесність, стриманість, щедрість, старанність, лагідність, доброзичливість, смиренність - основні чесноти кожного, а вихователя найперше.

Нині увага до етики взаємин зростає в багатьох державах та освітніх системах. Л. Шевченко стверджує, що педагогічна етика - це складник етики, що віддзеркалює особливості функціонування моралі в умовах цілісного педагогічного процесу, наука про різнобічні аспекти моральної діяльності педагога [16].

Важливого значення педагогічній етиці, а саме емоційно-чуттєвій сфері педагога як засадничій у іiї формуванні, надає I. Зязюн [4; 11]. Науковець зазначає, що задля розвитку педагогічний талант потребує правильного живлення, правильної етики, правильної гігієни, правильного вправляння. Поживою для таланту є все, що підносить і ушляхетнює людський дух, людську думку. Такий вплив мають насамперед етичні враження.

Г. Васянович наголошує, що завданнями педагогічної етики в сучасних умовах ринкових відносин слід уважати проблеми формування гуманістичної спрямованості особистості педагога; вияв чинників, які сприяють високому рівню моральності або, навпаки, гальмують процес моральної стійкості; дослідження зв'язків між моральним досвідом дітей та їх батьків [1].

Отже, педагогічна етика грунтується на моральності ставлення до духовного світу дитини як культурної цінності. Саме в гуманістичній спрямованості дій вихователя виявляються його повага до особистості дошкільника, колег, батьків і прагнення зберегти їхню гідність, сприяти подальшому розвитку. Тому взаємини між учасниками навчальновиховного процесу ДНЗ, передбачаючи організацію спільної діяльності (спілкування), мають регулюватися через дотримання моральних норм і правил.

Meта cmammi - полягає в теоретичному обгрунтуванні етичних принципів взаємодії вихователя з учасниками педагогічного процесу.

Згідно з позицією сучасних науковців, роботу дошкільних навчальних закладів необхідно здійснювати на основі нової філософії взаємодії. Йдеться про те, що за виховання дітей несуть відповідальність батьки, а всі інші соціальні інститути (у нашому випадку ДНЗ) мають допомогти, підтримати, спрямувати та доповнити їхню виховну діяльність [5]. Стає зрозумілим, що сутність такої взаємодії полягає в узгодженні вимог, дій дошкільного закладу і сім'ї як суб'єктів виховання дитини, активне залучення батьків до педагогічного процесу, надання допомоги педагогічному колективу дошкільного закладу. Від того, наскільки стосунки між вихователем і батьками будуть узгоджені, настільки залежить успіх формування особистості загалом.

Очевидним є те, що саме завдяки співпраці дорослих людей створюється повноцінне соціальне середовище розвитку малюка. Ідеться не тільки про зовнішні, організаційні умови (єдиний режим життя, харчування, єдині правила поведінки вдома й у дитячому садку), а й єдині норми та стиль спілкування дорослих з дитиною, гуманне ставлення до малюка, повага до його потреб у спілкуванні з дорослими і товаришами, у цікавих іграх, спостереженнях, предметно-практичній діяльності, а також у схваленні, позитивній оцінці батьками, вихователями особистості дитини загалом і конкретних їі вчинків або дій [5]. Отже, взаємовідносини в системі «педагог - сім'я - дитина» необхідно будувати відповідно до вимог педагогічної етики за провідної ролі ДНЗ і активної участі батьків.

Головною моральною основою етики педагогічної взаємодії має бути добре, гуманне ставлення до людей, яке включає повагу до особистості, співчуття, любов. Там, де починається цей принцип, немає місця байдужості, апатії вихователя. Виявляти повагу до особистості - означає уважно ставитися до неї, виявляти довіру, справедливість, доброзичливість, увічливість. Із повагою несумісні насильство, порушення прав і свобод, жорстокість, приниження. 
У ставленні до дітей надзвичайно важливо вміти поєднувати вимогливість і повагу. Співчувати дитині - означає поділяти їі радість чи сум, захоплюватися її успіхами, жаліти в невдачах. Із поняттям «співчуття» тісно пов'язане поняття «милосердя», що може бути визначене як діяльне прагнення допомогти кожному, хто має в тому потребу.

Поняття «любов» сучасні мислителі здебільшого розглядають як відповідальність «Я» за «Тебе», прийняття однією людиною іншої з усіма її радощами, болями та сподіваннями. Любов - та єдина сила, яка дає можливість наблизитися до дитини, зирнути в іiї світ, а іноді душею ототожнитися 3 нею. Любов відкриває в людині найблагородніші начала - у любові, ми стаємо максимально далекими від корисливості або споживацтва. Любов педагога до дітей - одна з головних передумов досягнення належної результативності виховання через те, що має величезну силу позитивного впливу. Якщо ж педагог не любить дітей, він не зможе захопити їх своїми інтересами, прагненнями, зрозуміти їхню душу.

Видатний педагог В. Сухомлинський, формулюючи побажання молодим педагогам, підкреслював, що виховання дітей, любов і повага до них, дружба з ними - усе це повинно бути самою суттю духовного життя вихователя [14]. Він мав на увазі не сюсюкання, не захвалювання, не вседозволеність, а мудру людську любов, одухотворену глибоким знанням людського досвіду, розумінням усіх слабких і сильних сторін особистості любов, що застерігає від нерозсудливих учинків і надихає на вчинки чесні, благородні, любов, що вчить жити, любов, у якій поєднується сердечна ласка з мудрою суворістю й вимогливістю.

Принцип педагогічного гуманізму є визначальним у системі педагогічної етики. Окрім любові, милосердя, співчуття, довіри, справедливості, доброзичливості, він передбачає повагу до прав $і$ свобод особистості; розуміння внутрішньої самобутності, свободи; розвиток позитивного ставлення до інших людей.

До принципів педагогічної моралі також відносимо: принцип оптимізму, законності, справедливості, гендерної рівності, незалежності та інші. Їх дотримання дошкільним педагогом означає виконання певних вимог, що виражають основний напрям його поведінки щодо інших суб'єктів педагогічної взаємодії. Такими суб'єктами є діти, батьки вихованців, члени педагогічного колективу та керівництва дошкільного навчального закладу, а також безпосередньо педагог (його ставлення до самого себе). Етичні принципи, розкриваючи зміст моральності, спрямовують діяльність педагога та сприяють регуляції стосунків з іншими учасниками навчально-виховного процесу $[1 ; 2 ; 10]$.

Для принципу педагогічного оптимізму характерне позитивне світосприймання. Світ дитинства й оптимізму - це єдиний щасливий світ. Для дитинства оптимізм - те ж саме, що гра барв для веселки: немає оптимізму - немає й дитинства. Душевне піднесення, злет мають відбутися в дитини самостійно, але вихователь повинен вміти допомогти цьому. Оптимізм - це ніби чарівне кольорове скло, крізь яке навколишній світ здається дитині великим чудом. Вона не просто бачить і розуміє, а емоційно оцінює, любить, захоплюється, дивується, ненавидить, прагне стати на захист добра проти зла. Не можна відібрати в дитини цього чарівного скельця. Не можна перетворювати эї в холодного, розсудливого резонера [14].

Принщип справедливості означає, що у своїй діяльності вихователь є небайдужим, однаково доброзичливим і прихильним до всіх учасників навчально-виховного процесу, незалежно від віку, особливостей характеру, здібностей, статі, раси, національності, віросповідання, соціального стану, політичних поглядів, місця проживання, громадянства та інших ознак, включаючи матеріальне становище.

Під час оцінки досягнень дітей вихователь має прагнути до об'єктивності й справедливості. Дошкільний педагог відкриває радість спілкування, радість спільного пізнання, сумісної праці, гри, відпочинку. Він надає можливість реалізації права дитини вільно висловлювати свої думки та мати власну позицію. За таких умов у здійсненні навчально-виховної діяльності вихователь керується принцииом індивідуальної 
відповідальності за його поведінку. Він виховує чесне і благородне ставлення до навколишнього світу, до себе, розвиває віру у вихователів і товаришів.

Вихователь у свій діяльності має керуватися й принципом краси, або естетичної привабливості спілкування. Етичні правила цього процесу тісно пов'язані з естетикою. Адже краса - сестра добра, моральності. Естетичні та моральні оцінки тісно переплітаються, коли йдеться про людину, їі характер, учинки. Однак вони можуть і не збігатися. Буває, що увага до людини знецінюється неестетичною формою вираження.

Важливим у регуляції стосунків між учасниками навчально-виховного процесу є також принции законності. Він передбачає дотримання Конституції і законів України, діючих нормативних документів, що регламентують педагогічну діяльність. Цей принцип виражається у почутті власної гідності, внутрішньої свободи, дисциплінованості, у повазі й довірі до інших громадян і до державної влади, здатної виконувати свої обов'язки, у гармонійному поєднанні патріотичних, національних, наднаціональних, загальнолюдських почуттів. Педагог несе персональну відповідальність перед законом, державою, народом за формування моральних, громадянських якостей вихованців.

Особливістю педагогічної взаємодії є незалежність вихователя в дотриманні своїх професійних прав і обов'язків, що передбачає його свободу від будь-якого зовнішнього тиску чи втручання в діяльність. Хоча сам педагог не завжди $є$ суб'єктом педагогічного процесу, особливо в умовах командної ієрархії керівництва освітніми закладами. Для вихователя, свідомість якого вільна від стереотипів, найбільшу цінність має не послух дитини, а іiі моральні якості, самовизначення, прагнення вдосконалитися, що зумовлює в майбутньому до найповнішої самореалізації в житті [6].

Вихователь не повинен допускати у своїй професійній діяльності компромісів, якщо такі компроміси не збігаються з інтересами мети освітнього процесу. Основою прийняття ним фахових рішень не можуть бути мотиви матеріальної та особистої вигоди, кар'єри, задоволення власних амбіцій, а також інтереси членів сім’ї, родичів та друзів. Водночас дошкільний педагог має право на вільний творчий педагогічний експеримент у межах чинного законодавства України. Він самостійно може обирати стиль спілкування, заснований на взаємній повазі, може на власний розсуд застосовувати види виховної діяльності і впроваджувати нові методи виховання, якщо вони 3 професійної точки зору придатні, відповідальні і пристойні.

У виховному та освітньому процесі дошкільному педагогові варто дотримуватися принципу рівності чоловічої та жіночої статі та сприяти розкриттю знань дітей про роль чоловіків і жінок, що відведена їм у суспільстві. Із ним пов'язаний принцип плюралізму, який полягає в умінні та можливості толерантно ставитися до світогляду, переконань, позицій, думок і почуттів інших людей, не ображати, не принижувати їхню гідність, визнавати, що кожна людина може змінитися, якщо вона помиляється, має можливості для морального зростання.

Неабияке значення у стосунках має врахування принцииу доцільності, зручності, що орієнтує на вибір i творче застосування етичних норм i правил спілкування в нестандартних ситуаціях. Дотримуючись його у виховному процесі, вихователеві слід пам'ятати, що зручно та приємно має бути не лише йому самому, а й тим людям (дітям і дорослим), із якими він взаємодіє. Морально поводитися, на нашу думку, необхідно не для того, щоб тебе вважали вихованим, а щоб іншим було легше. Сам по собі, без щирості, доброти, делікатності етикет - ніщо, а знання вимог педагогічного етикету ще не свідчать про вихованість педагога.

Отже, можемо стверджувати, що основним принципом педагогічної моралі є принųип «твори добро», який передбачає спрямування діяльності педагога на всебічний розвиток дитини та виконання своєї місії з любов'ю та повагою до життя, гідності особистості. У стосунках 3 іншими учасниками навчально-виховного процесу вихователь повинен дотримуватися принципів загальнолюдської та професійної моралі, бути чесним та беззастережно відданим своїм обов'язкам. Саме він у всіх випадках запобігає заподіянню 
шкоди дитині, не наражає іiі на небезпеку, а захищає від будь-яких шкідливих впливів. Вихователь не може пропонувати дошкільнику знання, які загрожують його життю або суспільству загалом, використовувати методи, які негативно впливають на психічний або фізичний стан здоров'я дитини.

Допомагають гуманізувати міжособистісні стосунки, роблять їх людяними, природними, невимушеними, доброзичливими терпимість та толерантність. Етичне ставлення як до дорослих, так і до дітей виявляється у привітності, сердечності і тощо.

Найбільш значущими в педагогічній діяльності, окрім знань про моральні вимоги, $є$ морально-педагогічні переконання та потреби, що передбачають внутрішнє органічне прийняття вимог. Наявність морально-педагогічної потреби в дотриманні вимог педагогічної етики організовує волю, почуття й стає змістом особистого інтересу вихователя до професійної діяльності. Коли етичні вимоги стають внутрішньою справою, бажанням й інтересом вихователя, вони мобілізують думки й енергію для відповідної поведінки, побудови моральних взаємин з учасниками педагогічного процесу, стають стійкими якостями людини, справою обов'язку й совісті, честі й достоїнства, справедливості й добра.

Уважаємо, що відповідність вимогам педагогічної моралі - мірило суспільної цінності й авторитету вихователя, показник його реального достоїнства як педагога, основа для самоповаги й самоствердження.

Названі принципи, на нашу думку, можуть бути критеріальними показниками моральної компетентності вихователя, регуляторами педагогічних взаємин, а їхнє дотримання передбачає наявність у дошкільного педагога таких морально-психологічних якостей: любові до дітей, чуйності, витримки, принциповості, спостережливості, урівноваженості, послідовності, поміркованості, розсудливості, справедливості, доброзичливості, передбачливості, щирості, відвертості, уважності, довірливості, кмітливості, творчості тощо. Вірність принципам педагогічної моралі - справа честі і совісті вихователя, мірило його суспільної цінності і поваги, основа для самоповаги i самоствердження. Адже він є носієм морально-етичних норм і чеснот, взірцем перед вихованцями, їхніми батьками, педагогічним співтовариством та суспільством загалом.

Отже, необхідно, щоб знання вимог педагогічної моралі підкріплювалися внутрішньою високою моральністю, духовністю педагога. Без цього від етикету мало користі. Просто знати принципи педагогічної моралі недостатньо. Треба, щоб вони ввійшли у звичку, стали повсякденною потребою, моральним регулятором поведінки та стосунків.

Уважаємо, що систематизація професійних моральних норм, правил, розроблення етичного кодексу педагога потребують подальшого аналізу та дослідження.

\section{Література}

1. Васянович Г. Педагогічна етика: [навч.-метод. посібник] / Г. Васянович. - Львів : Норма, 2005. - 344 с. 2. Гриценко Т. Б. Етика ділового спілкування: [навч. посіб.] / Т. Б. Гриценко. - К. : Центр учбової літератури, 2007. - 344 с. 3. Етичний кодекс українського педагога (проект) [Електорнний ресурс]. - / укладачі : Мовчан П. І., Березанська Н. І., Вдовиченко А. М., Тарасов О. М. // [Електронний ресурс]. - Режим доступу : http://rmu.luguniv.edu.ua/img/ekup.pdf 4. Зязюн I. Педагогіка добра : ідеали і реалії: [навч.-метод. посіб.] / І. Зязюн. - К. : Вид-во МАУП, 2000. 312 с. 5. Івах С. М. Методика співпраці дошкільних закладів з родинами: [навч. посіб.] / С. М. Івах, Т. І. Пантюк. - Дрогобич: Ред.-вид. відділ ДДПУ імені Івана Франка, 2011. - 145 с. 6. Кобрій О. Основи педагогіки : [навч. посіб.] / О. Кобрій. - Дрогобич : Ред.-вид. відділ ДдПУ імені Івана Франка, 2008. - 263 с. 7. Малахов В. А. Етика: курс лекцій : [навч. посіб.] / В. Малахов. - [4-те вид.]. - К. : Либідь, 2002. - 384 с. 8. Мовчан В. С. Етика : [навч. посіб.] / В. С. Мовчан. - К. : Знання, 2007. - 483 с. 9. Назаренко А. Сім'я і дошкільний заклад / А. Назаренко // Дошкільне виховання. - 1995. - № 8. - С. 10-11. 10. Наумчик В. Этика педагога: [учеб.-метод. пособ. для студ.] / В. Наумчик, Е. Савченко. - Минск: Университетское, 1999. - 216 с. 11. Педагогічна майстерність: [підручник] / І. А. Зязюн, Л. В. Крамущенко, І. Ф. Кривонос та ін.; за ред. І. Зязюна [2-ге вид., допов. переробл.]. - К. : Вища школа, 2004. - 422 с. 12. Самойленко А. М. Моральноетичний портрет сучасного педагога / А.М. Самойленко // Наука та практика - 2007 : міжнародна 
науково-практична конференція : [зб. наук. пр.] (11 - 15 лютого 2007 року). - Полтава : Громадська асоціація «Аграрна наука та практика», 2007. - С. 216-220. 13. Султанова Н. В. Педагогічна мораль як чинник формування етичних переконань і потреб соціального педагога / Н. В. Султанова // Таврійський вісник освіти: науково-методичний журнал. - 2011. - №4 (36). - С. 24-30. 14. Сухомлинський В. О. Лист про педагогічну етику / В. О. Сухомлинський // Вибрані твори в 5ти томах / В. О. Сухомлинський. - К. : Рад. шк., 1977. - С. 591-600. 15. Хоружа Л. Етична компетентність учителя як основа реалізації гуманістичної парадигми освіти / Л. Хоружа // Шлях освіти. - 2003. - № 3. - С. 27-33. 16. Шевченко Л. Практическая педагогическая этика: экспериментально-дидактический комплекс / Л. Шевченко. - М. : Собор, 1997. - 506 с.

УДК 378.041

Є. Д. Харькова, викладач,

Сумський державний педагогічний університет імені А. С. Макаренка

\section{ТЕНДЕНЦІЇ І ПЕРСПЕКТИВИ ТРАНСФОРМАЦІЇ ПЕРЕДШКІЛЬНОЇ ОСВІТИ В СУЧАСНОМУ ОСВІТНЬОМУ ПРОСТОРІ УКРАЇНИ}

Харькова Є.Д. Тенденції і перспективи трансформації передшкільної освіти в сучасному освітньому просторі України

У статті розглянуто проблему трансформації передшкільної освіти в сучасному освітньому просторі України, визначено провідні чинники передшкільної освіти, які зумовили виокремлення передшкільної освіти.

Ключові слова: передшкільна освіта, трансформація передшкільної освіти, сучасний освітній простір, зміст передшкільної освіти.

Харькова Е. Д. Тенденции и перспективы трансформации предшкольного образования в современном образовательном пространстве Украины.

В статье рассматривается проблема трансформации предшкольного образования в современном образовательном пространстве Украины, названы основные факторы, обусловившие выделение предшкольного образования.

Ключевые слова: предшкольное образование, трансформация предшкольного образования, современное образовательное пространство, содержание предшкольного образования.

Kharkova E. D. Trends and prospects of transforming pre-school education in the modern educational environment in Ukraine.

The paper considers the problem of transformation of pre-school education in the modern educational environment of Ukraine, called factors leading pre-school education, have provided separation of preschool education.

Зміст державного стандарту України, перетворення іiї на самостійну державу, перехід до громадянського суспільства зумовили докорінне реформування й модернізацію системи освіти, зміни основних парадигм в освіті на всіх пї ланках, що у свою чергу, вимагає внесення відповідних змін до змісту освіти. У цьому зв'язку особливої уваги набуває дошкільна освіта як вихідна, початкової ланки загальної освіти. Провідними принципами української системи дошкільної освіти задекларовано в низці загальнодержавних нормативних документах, а саме: в Державній національній програмі «Освіта» (Україна XXI століття), Законі «Про дошкільну освіту», «Про охорону дитинства», Базовому компонентів дошкільної освіти, Державній цільовій програмі розвитку дошкільної освіти на період до 2017 року. В означених документах законодавчо закріплено прогресивні зміни, що відбулися в освітній політиці держави в період становлення незалежної України, а також прописано нові пріоритетні завдання подальшого розвитку системи дошкільної освіти. 